In cooperation with the U.S. Environmental Protection Agency

\title{
Construction of Shipping Channels in the Detroit River: History and Environmental Consequences
}

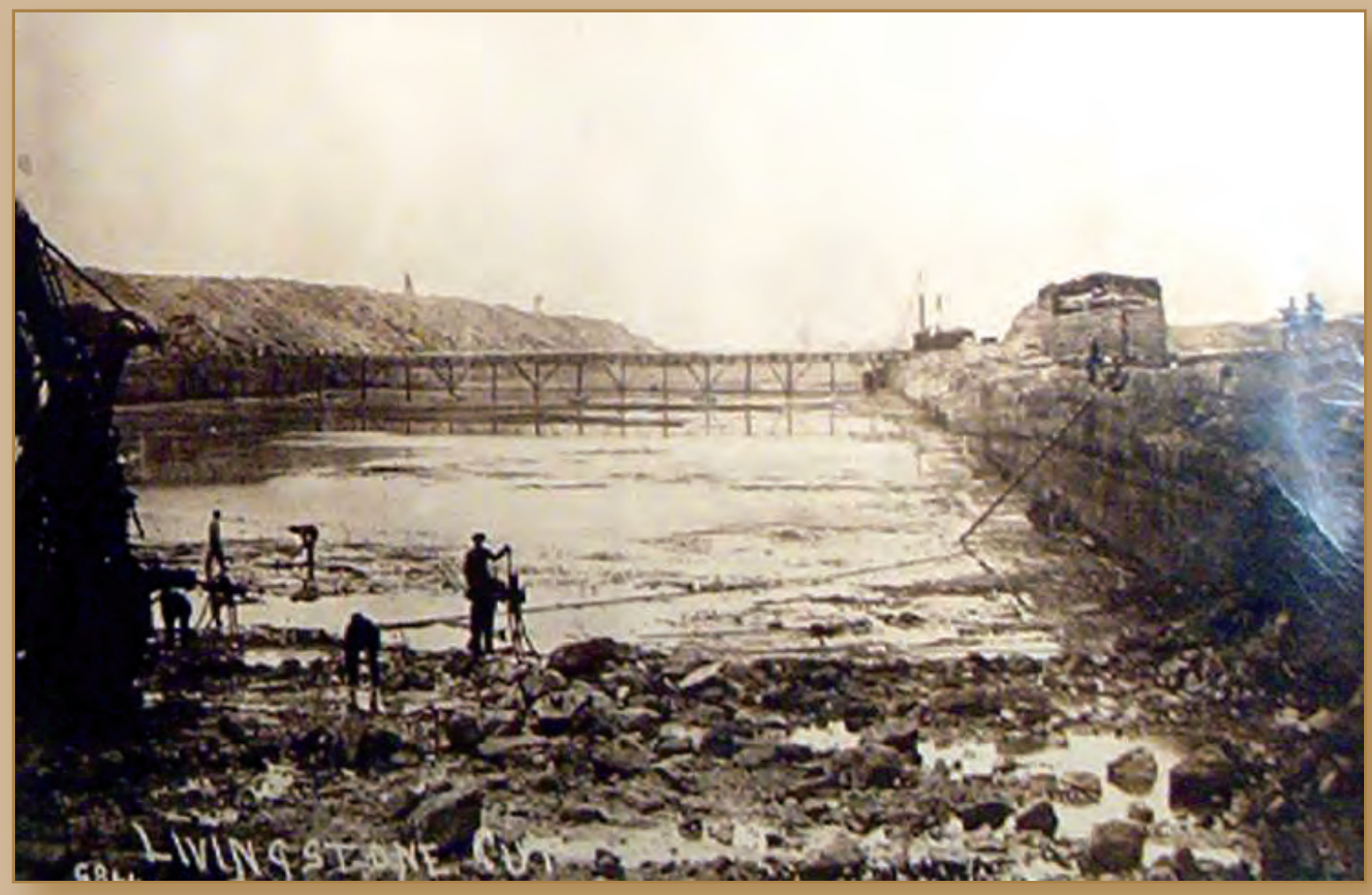

Scientific Investigations Report 2011-5122

U.S. Department of the Interior

U.S. Geological Survey 



\section{Construction of Shipping Channels in the Detroit River: History and Environmental Consequences}

By David H. Bennion and Bruce A. Manny

In cooperation with the U.S. Environmental Protection Agency

Scientific Investigations Report 2011-5122 


\title{
U.S. Department of the Interior \\ KEN SALAZAR, Secretary \\ U.S. Geological Survey \\ Marcia K. McNutt, Director
}

\author{
U.S. Geological Survey, Reston, Virginia: 2011
}

For more information on the USGS - the Federal source for science about the Earth, its natural and living resources, natural hazards, and the environment, visit http://www.usgs.gov or call 1-888-ASK-USGS.

For an overview of USGS information products, including maps, imagery, and publications, visit http://www.usgs.gov/pubprod

To order this and other USGS information products, visit http://store.usgs.gov

Any use of trade, product, or firm names is for descriptive purposes only and does not imply endorsement by the U.S. Government.

Although this report is in the public domain, permission must be secured from the individual copyright owners to reproduce any copyrighted materials contained within this report.

Suggested citation:

Bennion, D.H., and Manny, B.A., 2011, Construction of shipping channels in the Detroit River-History and environmental consequences: U.S. Geological Survey Scientific Investigations Report 2011-5122, 14 p.

\section{Cover photo:}

View of the Detroit River after construction of the Livingston Channel. 


\section{Contents}

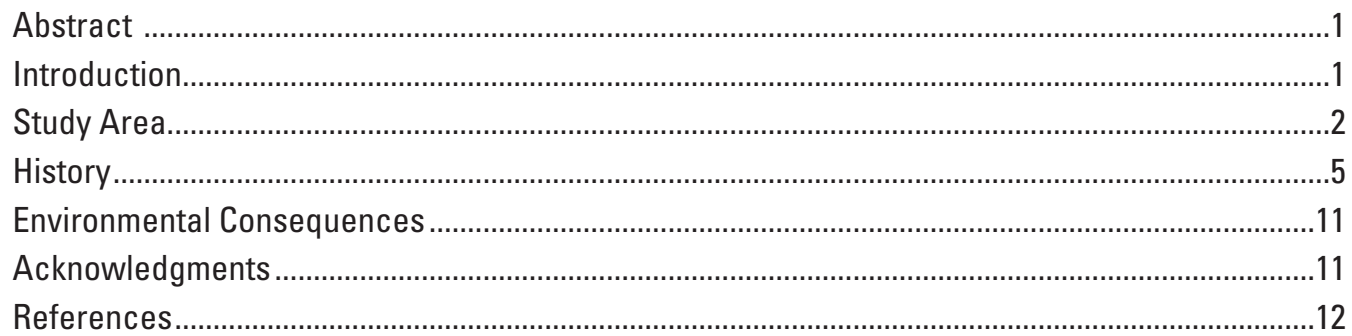

\section{Figures}

1. Map showing location of Detroit River study area ...............................................................

2. Photographs showing Detroit River bed before and after Livingstone Channel construction............................................................................. 4

3. Map showing Lower Detroit River shipping channels ...................................................6

4. Photograph showing Livingstone Channel rock cut within the cofferdam.......................7

5. Map showing extent of Detroit River channel construction and

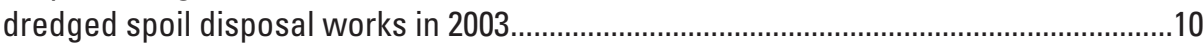




\section{Conversion Factors}

\begin{tabular}{lcl}
\hline \multicolumn{1}{c}{ Multiply } & By & \multicolumn{1}{c}{ To obtain } \\
\hline centimeter $(\mathrm{cm})$ & 2.54 & inch (in.) \\
meter $(\mathrm{m})$ & 3.281 & foot $(\mathrm{ft})$ \\
kilometer $(\mathrm{km})$ & 0.6214 & mile $(\mathrm{mi})$ \\
\hline & Area & \\
\hline hectare $($ ha $)$ & 2.471 & acre \\
square kilometer $\left(\mathrm{km}^{2}\right)$ & 247.1 & acre \\
square kilometer $\left(\mathrm{km}^{2}\right)$ & 0.3861 & square mile $\left(\mathrm{mi}^{2}\right)$ \\
\hline & Volume & \\
\hline cubic meter $\left(\mathrm{m}^{3}\right)$ & 35.31 & cubic foot $\left(\mathrm{ft}^{3}\right)$ \\
\hline & Water-withdrawal or flow rate \\
\hline liter per minute $\left(\mathrm{L} / \mathrm{min}^{3}\right)$ & 0.2642 & gallon per minute $\left(\mathrm{gal} / \mathrm{min}^{2}\right)$ \\
cubic meter per second $\left(\mathrm{m}^{3} / \mathrm{s}\right)$ & 35.31 & cubic foot per second $\left(\mathrm{ft}^{3} / \mathrm{s}\right)$ \\
\hline
\end{tabular}




\title{
Construction of Shipping Channels in the Detroit River: History and Environmental Consequences
}

\author{
By David H. Bennion and Bruce A. Manny
}

\section{Abstract}

The Detroit River is one of the most biologically diverse areas in the Great Lakes basin. It has been an important international shipping route since the 1820 s and is one of the busiest navigation centers in the United States. Historically, it supported one of the most profitable Lake Whitefish (Coregonus clupeaformis) commercial fisheries in the Great Lakes. Since 1874, the lower Detroit River has been systematically and extensively modified, by construction of deepwater channels, to facilitate commercial shipping. Large-scale dredging, disposal of dredge spoils, and construction of water-level compensating works has greatly altered channel morphology and flow dynamics of the river, disrupting ecological function and fishery productivity of the river and influencing Great Lakes water levels. From 1874 to 1968, major construction projects created 96.5 kilometers (60 miles) of shipping channels, removed over $46,200,000 \mathrm{~m}^{3}$ of material, covered 4,050 hectares ( 40.5 square kilometers) of river bottom with dredge spoils, and built 85 hectares of above-waterline compensating works at a total cost of US\$283 million. Interest by industries and government agencies to develop the river further for shipping is high and increasing. Historically, as environmental protection agencies were created, construction impacts on natural resources were increasingly addressed during the planning process and, in some cases, assessments of these impacts greatly altered or halted proposed construction projects. Careful planning of future shipping-channel construction and maintenance projects, including a thorough analysis of the expected environmental impacts, could greatly reduce financial costs and ecological damages as compared to past shipping-channel construction projects.

\section{Introduction}

As noted in Steedman and others (1996), "There is little doubt that retrospective study of Great Lakes aquatic ecosystems, including human uses and abuses, can underpin future efforts to conserve and restore aquatic habitats." Here, we review the historical development of deep-draft shipping channels in the Detroit River, including past decision making, and examine ecological ramifications of the St. Lawrence Seaway and proposed expansions of the seaway on the Detroit River.

The Detroit River is one of the busiest navigation centers in the United States (U.S. Army Corps of Engineers, 2004) and is one of the most biologically diverse areas in the Great Lakes basin (Bull and Craves, 2003). However, conflicting uses of the river and its connecting waters for commercial navigation, waste disposal, fishing, and recreation have resulted in many detrimental environmental changes in the river (Manny and others, 1988; Manny and Kenaga, 1991). Coupled with shoreline encroachment and the loss of coastal wetlands, alteration of riverbed substrates has reduced habitat for fish and wildlife in the Detroit River, leading to designation of the river as a binational Area of Concern (Manny, 2003). Such natural resources have high intrinsic value to society and are linked to sustainable economic prosperity in southeast Michigan (Hartig, 2003a). Restoration of fish spawning and nursery habitat in the Detroit River will require an understanding of where and why habitat for fish and wildlife was sustained in the river historically (Goodyear and others, 1982; Bull and Craves, 2003; Schloesser and Manny, 2007), how changes in the river environment affected fish and wildlife habitat and reproduction (Bull and Craves, 2003), and what conditions fish and wildlife require to reproduce and sustain themselves (Manny and Kennedy, 2002; Wei and others, 2004; Manny and others, 2005b; Schloesser and Manny, 2007).

Interest in expanding the Great Lakes seaway system is high and increasing. In June 2002, the U.S. Army Corps of Engineers (Corps) released a reconnaissance report on expanding the Great Lakes Seaway system entitled "Great Lakes Navigation System Review" (U.S. Army Corps of Engineers, 2003a). That report listed the following planning objectives: (1) contribute to the development and efficient utilization of the Great Lakes/St. Lawrence Seaway commercial navigation system infrastructure; (2) contribute to an increase in output of goods, services, and external economics of the Great Lakes/St. Lawrence Seaway system; (3) contribute to the maintenance of existing water levels and flows for the Great Lakes; and (4) contribute to the quality of the Great Lakes/ St. Lawrence Seaway environment, giving particular attention 
to the ecosystem and water quality of the lakes. The report explores options for increasing the depth of shipping channels in the Detroit River from $8.0 \mathrm{~m}$ to 9.1 and $10.7 \mathrm{~m}$. In November 2007 "The Great Lakes St. Lawrence Seaway Study Final Report" (Great Lakes St. Lawrence Seaway Study, 2007; http://www.glsls-study.com/English\%20Site/home.html) was released. This study involved Transport Canada, the Corps, the U.S. Department of Transportation, the St. Lawrence Seaway Management Corporation (Canada), Saint Lawrence Seaway Development Corporation (United States), Environment Canada, and the U.S. Fish and Wildlife Service. The objectives stated in the Memorandum of Cooperation that initiated this study are (1) evaluate the condition and reliability of the Great Lakes St. Lawrence Seaway system, including the relative benefits and costs of continuing to maintain the existing transportation infrastructure; (2) assess the engineering, economic, and environmental factors associated with the current and future needs of the Great Lakes St. Lawrence Seaway system and the transportation infrastructure on which it depends; and (3) identify factors and trends affecting the domestic and international marine transportation industries serving the Great Lakes St. Lawrence Seaway, including evolving intermodal linkages and transportation technologies. The purpose of our investigation was to evaluate the history and environmental consequences of past and proposed shipping channel construction in the Detroit River.

\section{Study Area}

The Detroit River is $51.5 \mathrm{~km}$ long, ranges from 1.2 to $6.6 \mathrm{~km}$ in width, and has an average discharge of 5,200 $\mathrm{m}^{3} / \mathrm{s}$ (Manny and others, 1988). It is part of the boundary between the United States and Canada and is spanned by three international crossings over which about US\$100 billion in trade is exchanged annually between Canada and the United States (Hartig, 2003b; fig. 1). The river supplies drinking water for over 5 million people and is used for recreational boating, hunting, and sport fishing that contribute significantly to local economies (Manny and others, 1988; Hartig, 2003b).

Historically, the river supported a large fishing industry (Roseman and others, 2007), and today, it is home to the Detroit River International Wildlife Refuge (http://www.fws.gov/ midwest/DetroitRiver/). The river once provided spawning habitat within the honeycombed limestone bedrock that has since been removed during creation of the shipping channels (fig. 2). The river now provides habitat to over 60 species of fish (Manny and others, 1988; LaPointe, 2005), 16 of which are threatened or endangered (http://www. huron-erie.org), and it is part of a Great Lakes flyway used by millions of migratory birds (Manny, 2003). It is also one of the busiest shipping lanes in the world. Approximately 68 million metric tons of commercial cargo is shipped on the river annually (U.S. Army Corps of Engineers, 2000, 2004). The river has been an important shipping route since the early 19th century. In 1907, more tonnage passed through Detroit than through London and New York combined (Nolan, 1997). The lower Detroit River has undergone extensive modifications, including construction of deepwater channels, to facilitate commercial shipping. Large-scale dredging and dumping of spoils and construction of compensating works has greatly altered flow patterns and destroyed historically and commercially significant Lake Whitefish (Coregonus clupeaformis) spawning grounds in the Detroit River (Roseman and others, 2007). This heritage fishery has begun to reestablish itself in the river during the past few years (Carl and others, 2007; Roseman and others, 2007). The lower river contains the Fighting Island, Trenton, Livingston, and Amhurstburg Channels (fig. 3). 


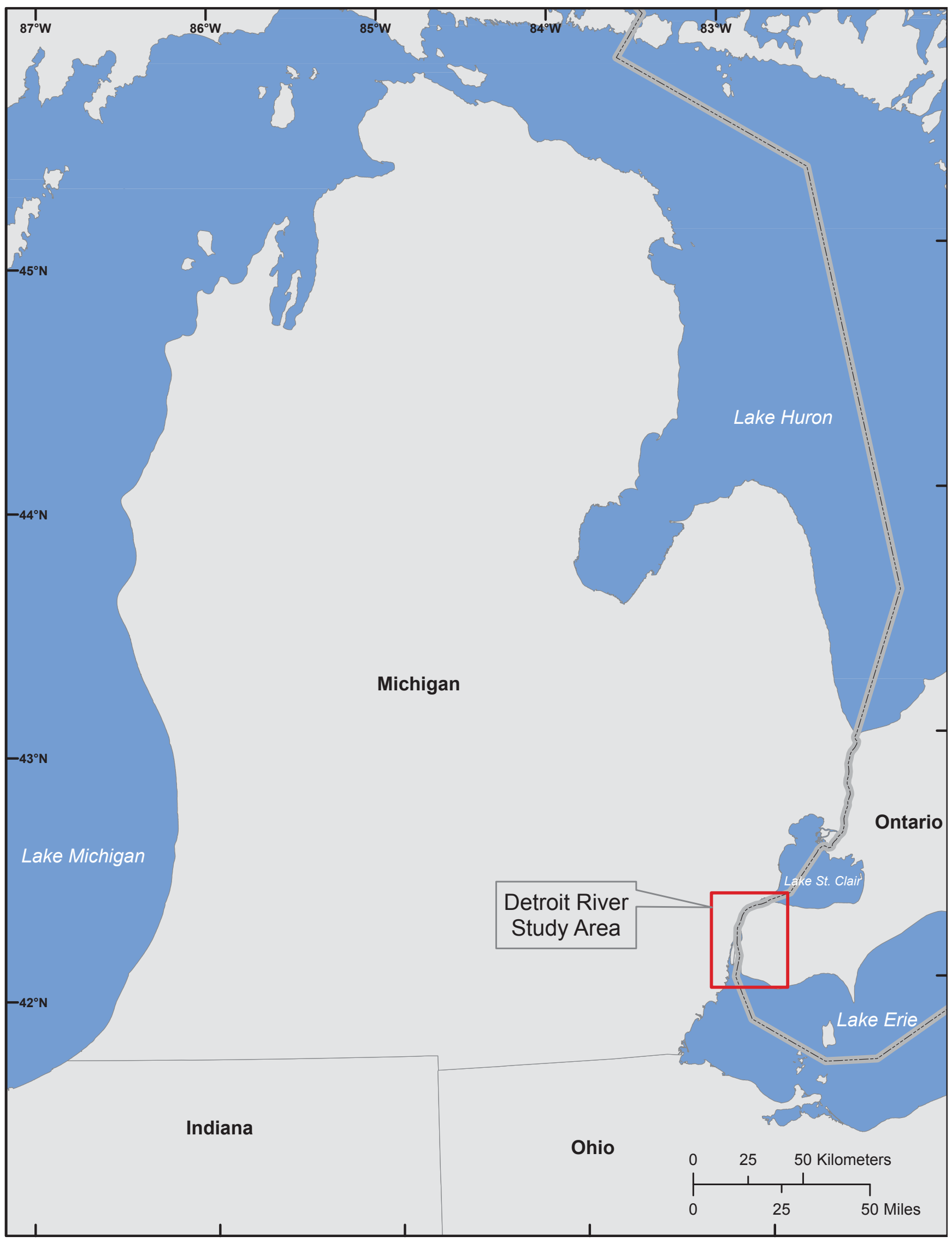

Figure 1. Location of Detroit River study area. 


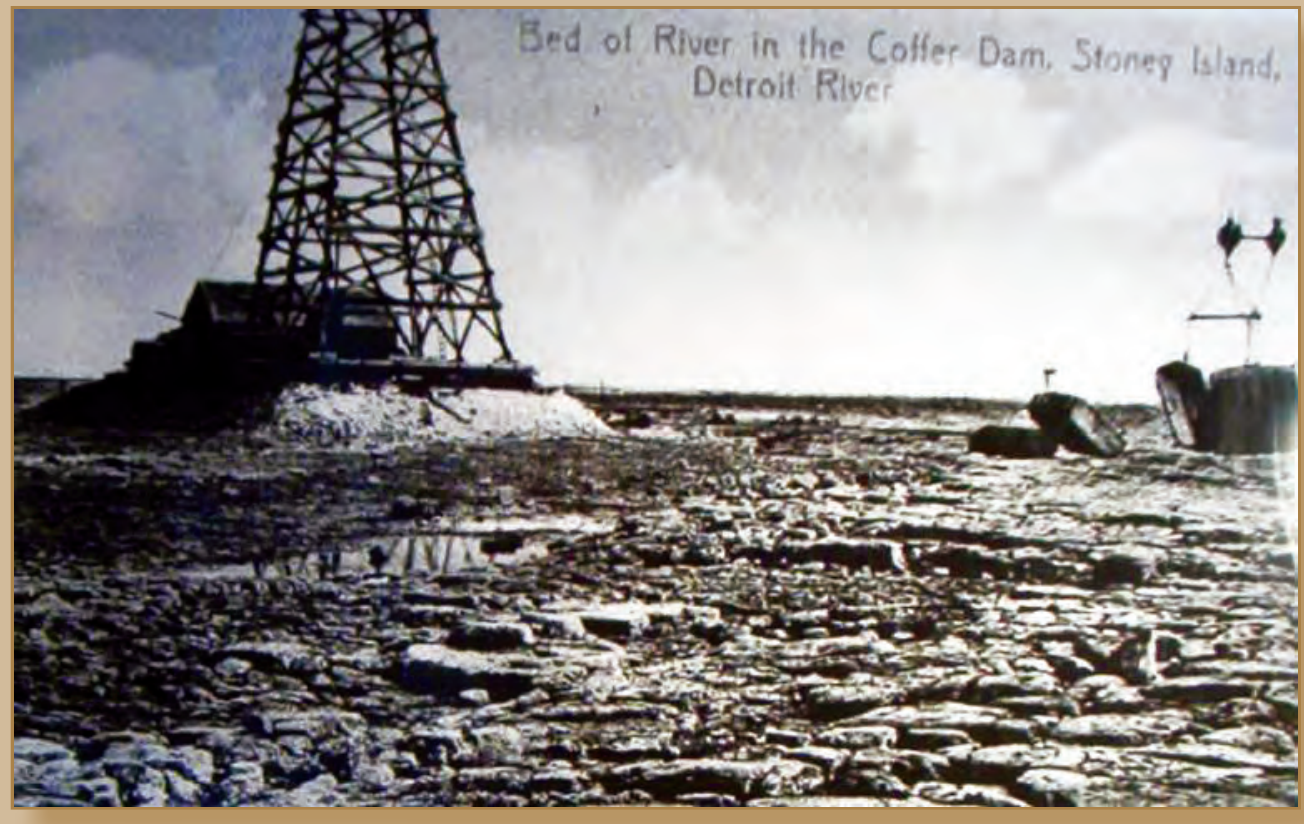

Before

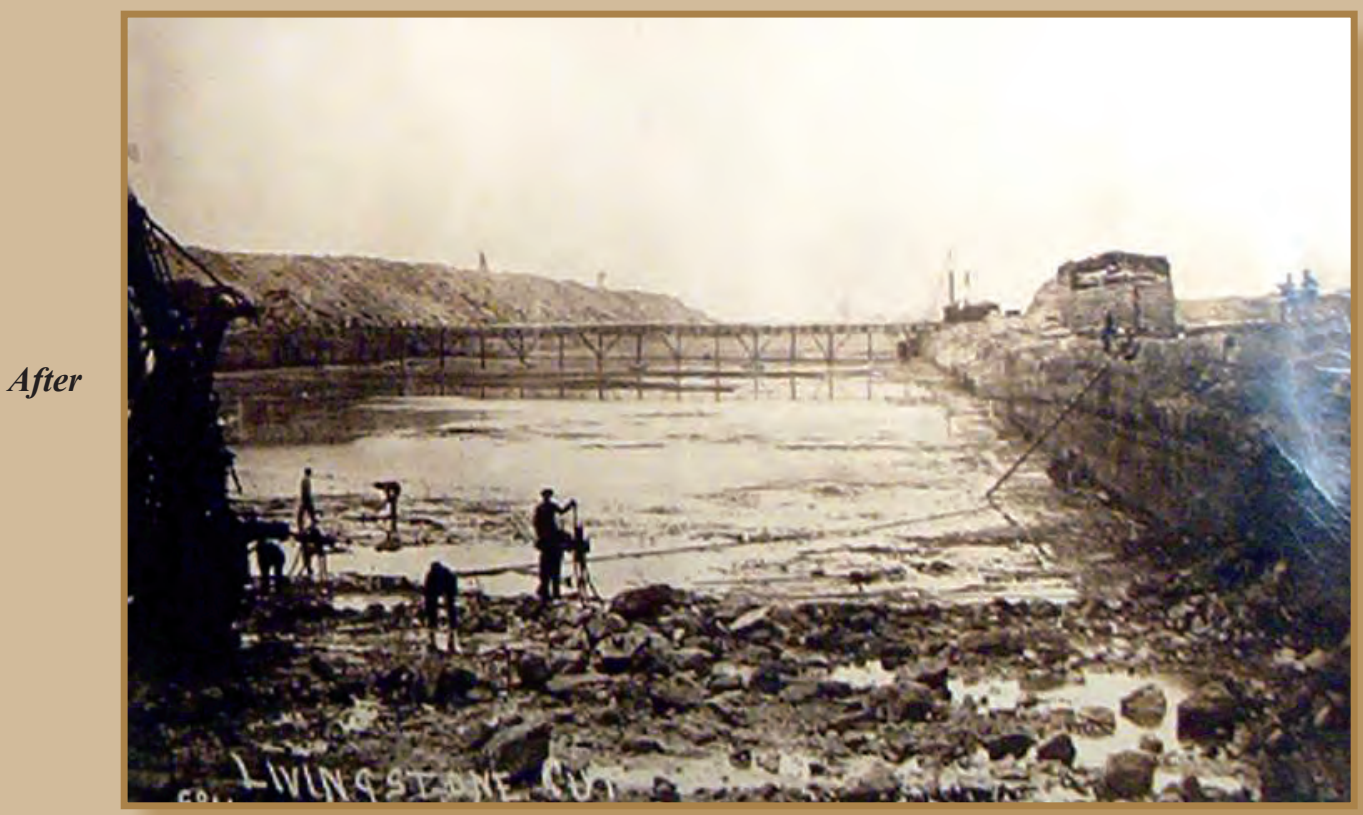

Figure 2. Detroit River bed before and after Livingstone Channel construction. 


\section{History}

The Detroit River has a long history of channel modifications, which were constructed from the late 1800 s to 1968 . In 1874 , the first construction project on the river started at Limekiln Crossing (fig. 3) near Bois Blanc Island (Larson, 1981). The original goal of a curved channel $914 \mathrm{~m}$ long, $91 \mathrm{~m}$ wide, and $6 \mathrm{~m}$ deep was modified in 1883 to create a straightened channel (Mansfield, 1899). In 1886, work to expand the channel to $122 \mathrm{~m}$ in width started, and in 1888 , work to secure a width of $134 \mathrm{~m}$ and a depth of $6.4 \mathrm{~m}$ began. Between 1901 and 1904, this channel was widened to $183 \mathrm{~m}$. The River and Harbor Act of 1892 called for a channel roughly $8 \mathrm{~km}$ long, $6.4 \mathrm{~m}$ deep and $244 \mathrm{~m}$ wide through soft sediments and limestone bedrock at the mouth of the Detroit River (fig. 3) and removal of shoal areas at the entrance to the river from Lake St. Clair. Partly in response to encouragement from shipping interests (Livingstone, 1891), this act also called for modification of a shipping channel in the Ballards Reef area (fig. 3) to a depth of $6.4 \mathrm{~m}$ and a width of $91 \mathrm{~m}$ from the head of Grosse Ile to the north end of Limekiln Crossing, just east of Stony Island. Previous work in the southern Ballards Reef area had created a smaller, 5.3-m-deep channel through solid rock (Horton and Grunsky, 1927; U.S. Army Corps of Engineers, 1938).

The River and Harbor Act of May 3, 1899, authorized a survey by the Corps to "secure a safe and convenient channel $21 \mathrm{ft}(6.4 \mathrm{~m})$ deep" from Detroit to Lake Erie (U.S. House of Representatives, 1900). All construction work on the Detroit River shipping channels between the head of Grosse Ile and the Detroit River lighthouse in Lake Erie was to achieve a minimum depth of $5.6 \mathrm{~m}$. Ongoing projects are outlined in this report, as well as three plans for a "safe and convenient" channel. The River and Harbor Act of June 13, 1902, selected one of the proposed routes, creating what has become the Amherstburg channel (fig. 3) in Canadian waters. The plan called for a channel with a minimum width of $183 \mathrm{~m}$ and $6.4 \mathrm{~m}$ depth (using the newly adjusted lowest mean monthly water stage of November 1895 as a reference). An estimate of cost shows that $79,400 \mathrm{~m}^{3}$ of bedrock needed to be removed from the areas of Ballards Reef (fig. 3) and Limekiln Crossing (fig. 3) (U.S. House of Representatives, 1904).

In 1906, at the request of Congress, the options for increasing the depth of all Detroit River shipping channels from 6.7 to $7.6 \mathrm{~m}$ were explored by the Corps. Within this investigation, it was noted that work had been in progress at the mouth of the Detroit River and at Limekiln crossing for the previous 30 years and that the full capacity of these channels had never been realized, because of the ongoing work. Ultimately, the increase in depths was not recommended by the Corps because the constant construction obstructed the full use of existing channels, and most harbors at the time were dredged to a depth of only $6 \mathrm{~m}$. While exploring these options, the Corps determined that the amount of freight passing through the river warranted construction of a second channel, with a depth of $6.7 \mathrm{~m}$ and extending from the deep water of Lake Erie, west of Bois Blanc Island, to the existing Ballards Reef channel. It was estimated that construction of this channel would require initial removal of $5,666,116 \mathrm{~m}^{3}$ of material (U.S. House of Representatives, 1906). The River and Harbor Act of March 2, 1907, officially approved construction of the Livingstone Channel (fig. 3) for downbound traffic west of the Amherstburg Channel, with a depth of $6.7 \mathrm{~m}$ and a width of $91 \mathrm{~m}$ across Limekiln Ridge (fig. 3) to Bar Point and $244 \mathrm{~m}$ from there to the $6.7-\mathrm{m}$ depth contour of western Lake Erie. To facilitate the removal of bedrock in the Limekiln Ridge area, a 1,768-m-long cofferdam was constructed to allow excavation in the dry (fig. 4). In 1909, the Corps and shipping interests proposed that the section of channel within the cofferdam be widened to $137 \mathrm{~m}$ to help avoid blockage in the event of vessel grounding and that a dike be constructed from the lower end of the dam to Bois Blanc Island to "avoid injurious cross currents." This dike was not built. These cross currents were the result of a natural channel that crossed the Livingstone Channel above Bois Blanc Island and carried 35 to 40 percent of the river's flow east of Stony Island (U.S. House of Representatives, 1910). This document also states that, when completed, the channel would provide a depth of about $7 \mathrm{~m}$ through Limekiln ridge where the original depth was approximately $1.2 \mathrm{~m}$. Before channel modification these rock shoals at Limekiln Ridge and Ballards Reef were a natural flow-control point for the water levels of lakes Michigan-Huron, because more than 60 percent of the total flow in the Detroit River passed between Stony Island and Canada (Horton and Grunsky, 1927).

The unmodified channel that ran from Fighting Island to the north end of Grosse Ile required vessels to make five turns within $5.3 \mathrm{~km}$. In 1911, directed by Congress, the Corps recommended straightening, widening and deepening this section of river. The new channel would be $6.7 \mathrm{~m}$ deep and $244 \mathrm{~m}$ wide (fig. 3 ) and provide a straight course from the head of Fighting Island to the head of Grosse Ile. The Corps estimated that about $1,277,877 \mathrm{~m}^{3}$ of material would need to be dredged to improve the existing channel but that this material would be removed from shoal areas mostly near the base of Fighting Island and the east side of Grassy Island (U.S. House of Representatives, 1911). The Report of the U.S. Commissioner of Fisheries for the fiscal year 1914 stated, "The whitefish fisheries of the Detroit River have been undergoing a steady decline for years" (Smith, 1915). The Grassy Island area was known for its productive capacity as a fishery for Lake Whitefish (Milner, 1873; Farmer, 1884). With approval by the River and Harbor Act of March 4, 1913, construction by the Corps of the Fighting Island channel from 1914 to 1915 removed the whitefish spawning habitat there, and spawning runs of Lake Whitefish disappeared from the Detroit River shortly thereafter (Smith, 1917; Roseman and others, 2007). 


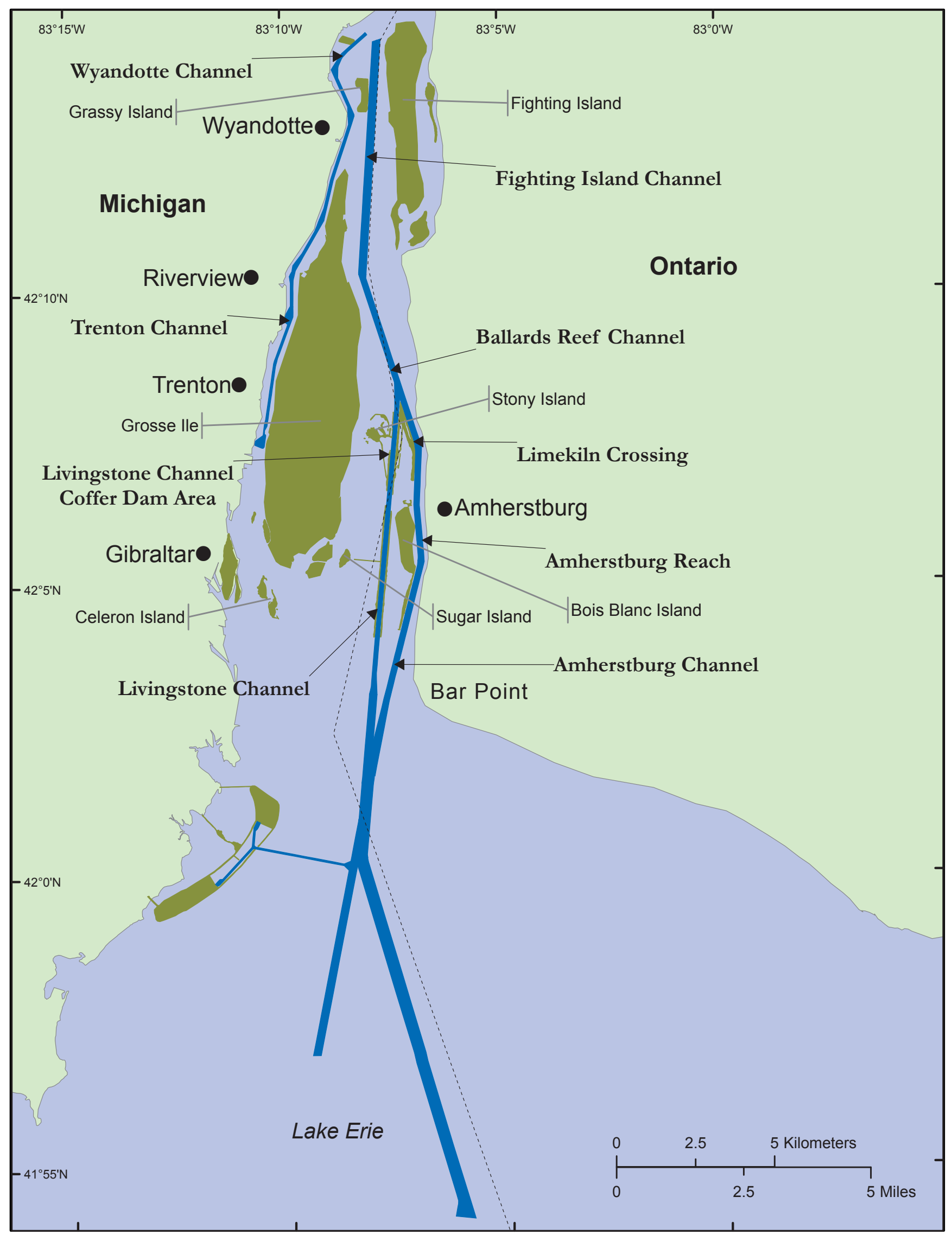

Figure 3. Lower Detroit River shipping channels. 


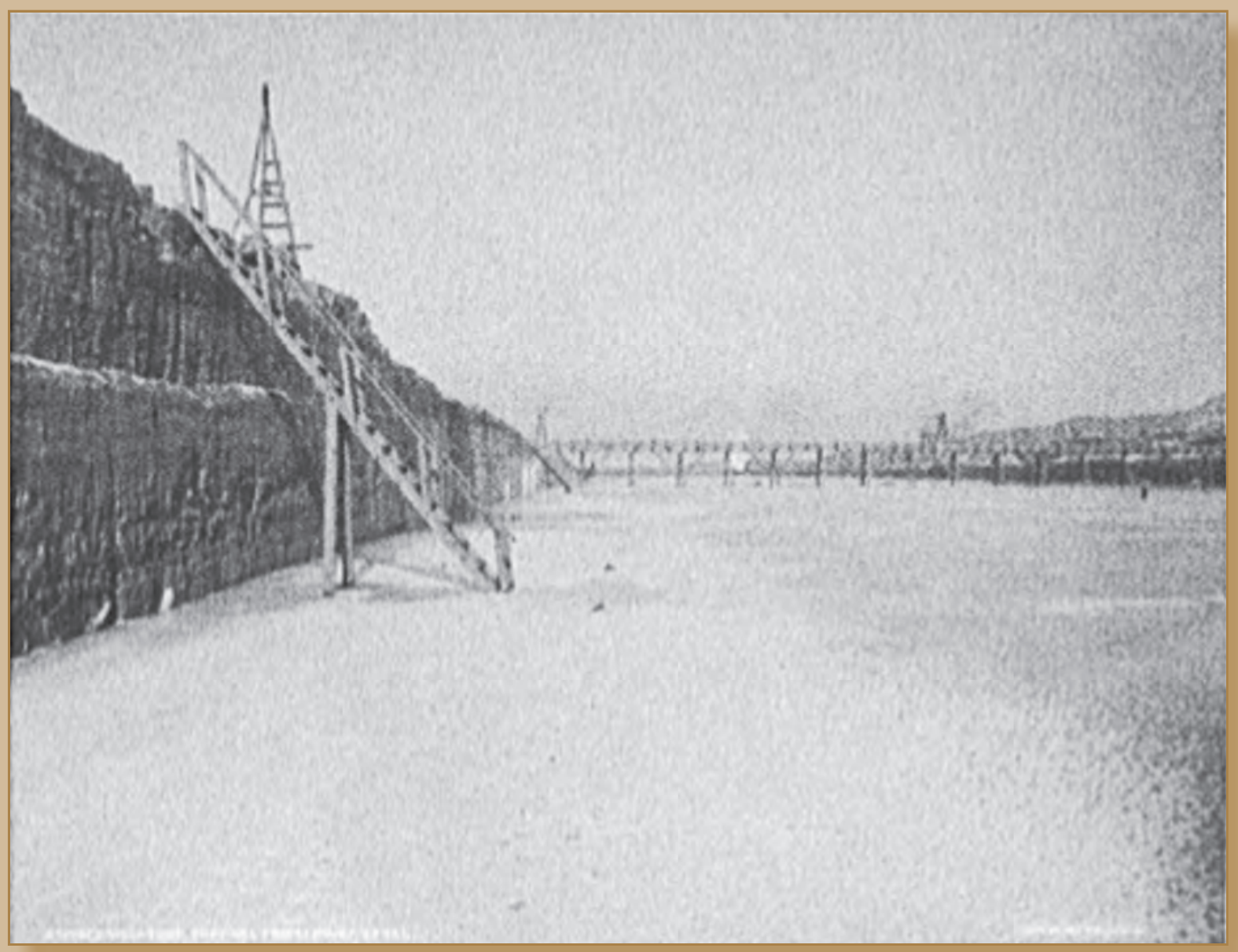

Figure 4. Livingstone Channel rock cut within the cofferdam. (Library of Congress [n.d.])

In 1917, the focus shifted back to the Livingstone Channel. The Corps recommended work to enlarge the portion through the rock cut from below the cofferdam to the junction with the Amherstburg Channel (fig. 3) from $91 \mathrm{~m}$ to $137 \mathrm{~m}$ in width and to enlarge the lower $3.6 \mathrm{~km}$ of the channel to a width of $244 \mathrm{~m}$ and a depth of $6.7 \mathrm{~m}$. Also proposed with this work was the construction of a dike along the west side of the rock-cut portion below the cofferdam and creation of a spoil bank to a height $0.3 \mathrm{~m}$ below water surface east of the cofferdam (creating Crystal Bay) between the Livingstone and Limekiln Channels. The new dike was 6,340 m long, with a 457-m gap just north of Bois Blanc Island. These works were recommended to both reduce the cross current (described as a "serious menace to navigation") and maintain water levels upstream of the channels. By 1937, in addition to the dike along the western side of the rock-cut portion, a dike along the eastern side of the channel had been added and a second cofferdam created to dewater this area for excavation. A cross dike running from the middle of the western dike towards Sugar Island was also constructed to help maintain water levels. Of note are the comments that “... the argument for widening this [Livingstone] channel at the present time does not rest upon the question of its capacity, but entirely upon the desirability of making the passage less dangerous," and regarding water levels, "As the data are not sufficient for an exact determination of the lowering due to the increase in section of the Livingstone Channel and of the extent of the compensation required, careful hydraulic and water-level measurements should be started at the time the proposed widening is undertaken, and these should be continued until the completion of the work" (U.S. House of Representatives, 1917). The report further discusses the new datum plane for project works and mentions that this new plane of reference leaves almost all previous works $0.06 \mathrm{~m}$ deficient in depth. In 1928, work was recommended by the Corps and approved by Congress to deepen the Livingstone and Fighting Island Channels to $7.6 \mathrm{~m}$ in soft material and to $7.9 \mathrm{~m}$ in ledge rock. Widening the rock-cut portion of the Livingstone Channel to $183 \mathrm{~m}$ was also suggested but not undertaken. By 1928, US\$160 million had been spent by the United States on navigation improvements 
throughout the Great Lakes (U.S. House of Representatives, 1928). In 1927 and later, the Detroit River channel modification, combined with the work that was done upstream in the St. Clair River, was reported to be responsible for a permanent 20- to 25-cm drop in the water levels of Lakes Michigan and Huron (Derecki, 1985; Quinn, 1985).

Prior to federal involvement, Detroit Edison Co. had dredged an area of the river bottom in the Trenton Channel in front of their electric power generating plant in Trenton, Mich. In 1935, construction began on a short channel to Wyandotte, Mich., $6.4 \mathrm{~m}$ deep and $91 \mathrm{~m}$ wide (fig. 3) through the shoals just north of Grassy Island from the deep water at the head of the Fighting Island channel to Wyandotte. In 1937, construction in the Trenton Channel of a turning basin west of Grosse Ile was approved by Congress (U.S. Senate, 1949). This channel extended from the upper Grosse Ile Bridge south to a turning basin $518 \mathrm{~m}$ below the lower Grosse Ile Bridge and was $6.4 \mathrm{~m}$ deep and $76 \mathrm{~m}$ wide, with a width of $91 \mathrm{~m}$ below the lower Grosse Ile Bridge (fig. 3). The turning basin was the same depth and occupied an area of $7 \mathrm{ha}$. Also as part of this project, the shoal area at the head of Grosse Ile was removed. Built mostly to transport materials to industry and the Detroit Edison powerplant (U.S. Senate, 1949), these channels were opened for commerce on July 22, 1940 (U.S. Senate, 1949). The north end of the river received Federal government attention again with a 1941 investigation into improving an existing, privately funded channel north of Belle Isle from Windmill Point to Fairview slip, just west of the Detroit Edison Conner's Creek powerplant. This is a side channel extending from near the end of the Lake St. Clair shipping channel, which extends into the mouth of the Detroit River. The existing channel had a controlling depth of $5.9 \mathrm{~m}$. (U.S. House of Representatives, 1946). The inbound tonnage in 1941 for the section of river in question was reported to be 999,718 metric tons, whereas outbound tonnage was only 74,843 metric tons. The proposed project was for a channel $6.4 \mathrm{~m}$ deep (with a 0.6-m overdepth) and $61 \mathrm{~m}$ wide. A 1942 Report to the Board of Engineers of Rivers and Harbors stated, "In view of the urgent nature of the requests for enlarging the channel, no public hearing was held, but written communications urging, or signifying approval of, the proposed improvements were received from practically all of the local industries making use of the terminal facilities ...." (U.S. House of Representatives, 1946). Also within this report is one of the earliest environmental impact statements made in reporting Detroit River projects to the U.S. Congress. It states, "No questions of water power, protection from floods, wildlife preservation, abatement of pollution, irrigation, or land reclamation are encountered in connection with the improvement proposed herein" (U.S. House of Representatives, 1946). This project was approved by the congressional act of March, 2, 1945 (U.S. Army Corps of Engineers, 2003b).

In 1946, an extensive review of existing conditions and recommendations for improvements throughout the Great Lakes seaway system was made. The improvements proposed for the river included deepening the western $91 \mathrm{~m}$ of the Amherstburg Channel and the section of Ballards Reef Channel above the Livingstone Channel to $8.2 \mathrm{~m}$ with a $0.6-\mathrm{m}$ overdepth. To compensate for the increased water flow through the bigger channels, large-scale compensating works between Gibraltar, Mich., and the southern end of Grosse Ile were proposed. The proposed works consisted of a series of dikes and a weir to close off most of the outlets to Lake Erie from the Trenton Channel reach of the river. The end result of these works would have reduced the outflow of the river from the Trenton reach to a confined channel $183 \mathrm{~m}$ wide and approximately $3 \mathrm{~m}$ deep. The location of these works was selected because "Reduction in flow by constricting works in the navigation channels is undesirable and impractical" (U.S. House of Representatives, 1948) and "The most satisfactory method, and probably the only practical one, of effecting (water level) compensation seems to lie in reducing the flow through Trenton Channel" (U.S. House of Representatives, 1948). Several companies, including Detroit Edison Co., Monsanto Chemical Co., and Socony Vacuum Oil Co., expressed concern about increased pollution and higher river water temperature that these proposed changes would generate in the river. This stretch of the river was their source of cooling water. Detroit Edison alone used 2,271,247 L/min, and an increase in temperature would mean a decrease in cooling efficiency. An increase in pollution would require the companies to install additional water-filtering mechanisms. The village of Trenton also lodged concerns about the project saying that "... reduction in flow in Trenton Channel to any extent approaching the stated percentages will have an adverse effect on the general health and welfare of the village and adjoining community, and will retard future civic and industrial development of the area ..." (U.S. House of Representatives, 1948). Governor Kelly of Michigan also included a letter stating his unfavorable opinion of the proposed works and suggesting that a study be undertaken to locate the necessary works entirely on the Canadian side of the river (U.S. House of Representatives, 1948). This plan was not completed (U.S. Senate, 1955).

The project to deepen sections of the Amherstburg and Ballards Reef channels was revisited in 1955 and again approved by Congress with the additions of a $0.6-\mathrm{m}$ increase of depth to the Fighting Island Channel and an 8.7-m depth throughout downbound and two-way channel except Lower Livingstone Channel, which was to be $8.8 \mathrm{~m}$ deep. A depth of $8.7 \mathrm{~m}$ was called for in the western portion of Hackett Reach and in Lake Erie from the mouth of the Detroit River through Pelee Passage Shoal. The Trenton Channel turning basin also would be extended. The plan for the compensating works, however, was greatly altered. It declared that “ . . . Lake St. Clair water levels at the present time are $0.07 \mathrm{ft}(0.02 \mathrm{~m})$ higher with respect to Lake Erie stages than they were 50 years ago as a result of overcompensation in the Detroit River when the Livingstone Channel was deepened to 27 feet (8.2 m)" (U.S. Senate, 1955). Instead of works at the mouth of the Trenton Channel, a dike extending downriver from the northern junction of the Livingstone and Amherstburg Channels, running to the west and parallel to the Amherstburg 
(Limekiln) Channel, reaching the existing dike at the head of the cofferdam was constructed. Also, starting at the southern tip of Bois Blanc Island, a dike would be constructed parallel to the Amherstburg Channel running 1,829 $\mathrm{m}$ downstream. Michigan's Governor Williams voiced his support for this project. However, no comments from private companies appear in the report. For the first time in these government reports, concerns about the possible ecological impacts of dredged-spoil placement were expressed, as well as concerns about losses of fish and wildlife habitat. It noted that although the dredging activities should have minimal impact to wildlife because they were to take place in existing shipping channels, disposal of spoils "could have effects of much greater concern to wildlife interests" (U.S. Senate, 1955) and that definite spoil-disposal plans should be created. In terms of the compensating works, it was stated that small changes in lake levels could affect extensive lake-fringe marshes, and the Corps of Engineers should consult with the Department of Conservation about the installation and operation of the compensating works. The report further states that cost of improvements in the Detroit River to June 30, 1954, totaled US\$22,595,148 and cost of maintenance totaled US $\$ 2,075,039$ (U.S. Senate, 1955; U.S. Army Corps of Engineers, 2003b).

In a 1959 report to Congress, plans for dredging the Trenton Channel were laid out. The plan called for an 8.2-m depth from the junction of the Wyandotte Channel and main river channel for $8.9 \mathrm{~km}$ to the upper Grosse Ile Bridge and an 8.5-m depth in the Trenton Reach extending 1,558 m downstream from the upper bridge. The $8.5-\mathrm{m}$ depth was to end at a 6-ha turning basin opposite the Gibraltar, MI McLouth Steel plant outside of the channel limits. The spoils would be placed in Lake Erie. The estimated cost of the project was US\$10.4 million, of which US\$8.6 million was to come from Federal funds. Concerns about environmental issues are mentioned throughout the report. A letter from the Department of the Interior in the report stated "The U.S. Fish and Wildlife Service reports that dredging operations will have an adverse effect on fish and wildlife resources downstream from the project due to the disturbance of deleterious materials including oil, sludge, and mill scale which lie in the channel bed. Damaging effects may extend into Lake Erie" (U.S. House of Representatives, 1959). The area was also recognized in this report as being important to fish and wildlife and for recreation in general. The Service requested that the dredging be done in the winter and that the Corps work with the Michigan Department of Conservation in the selection of spoil disposal areas. This work was completed in 1964 (U.S. House of Representatives, 1968). Major construction of the $96.5 \mathrm{~km}$ of shipping channels in the Detroit River was completed by 1964, although maintenance work is ongoing. From 1963 to 1998, a total of $11,671,163 \mathrm{~m}^{3}$ of material was dredged from the Detroit River (U.S. Army Corps of Engineers, 2003b) as part of maintenance efforts by the Corps. Projects that had been authorized but not completed were decommissioned by Congress in 1983 . As of 2003, US\$283 million had been spent on construction and maintenance of the Detroit River shipping channels (U.S. Army Corps of Engineers, 1915, 1938, 2003b). Estimates indicate that approximately $46,200,000 \mathrm{~m}^{3}$ (Moulton and Thieme, 2009) of material was removed from shipping-channel areas, $4,050 \mathrm{ha}\left(40.5 \mathrm{~km}^{2}\right)$ of river bottom was covered with dredge spoils, and 85 ha of above-waterline compensating structures were built (fig. 5; Manny and others, 2006). 


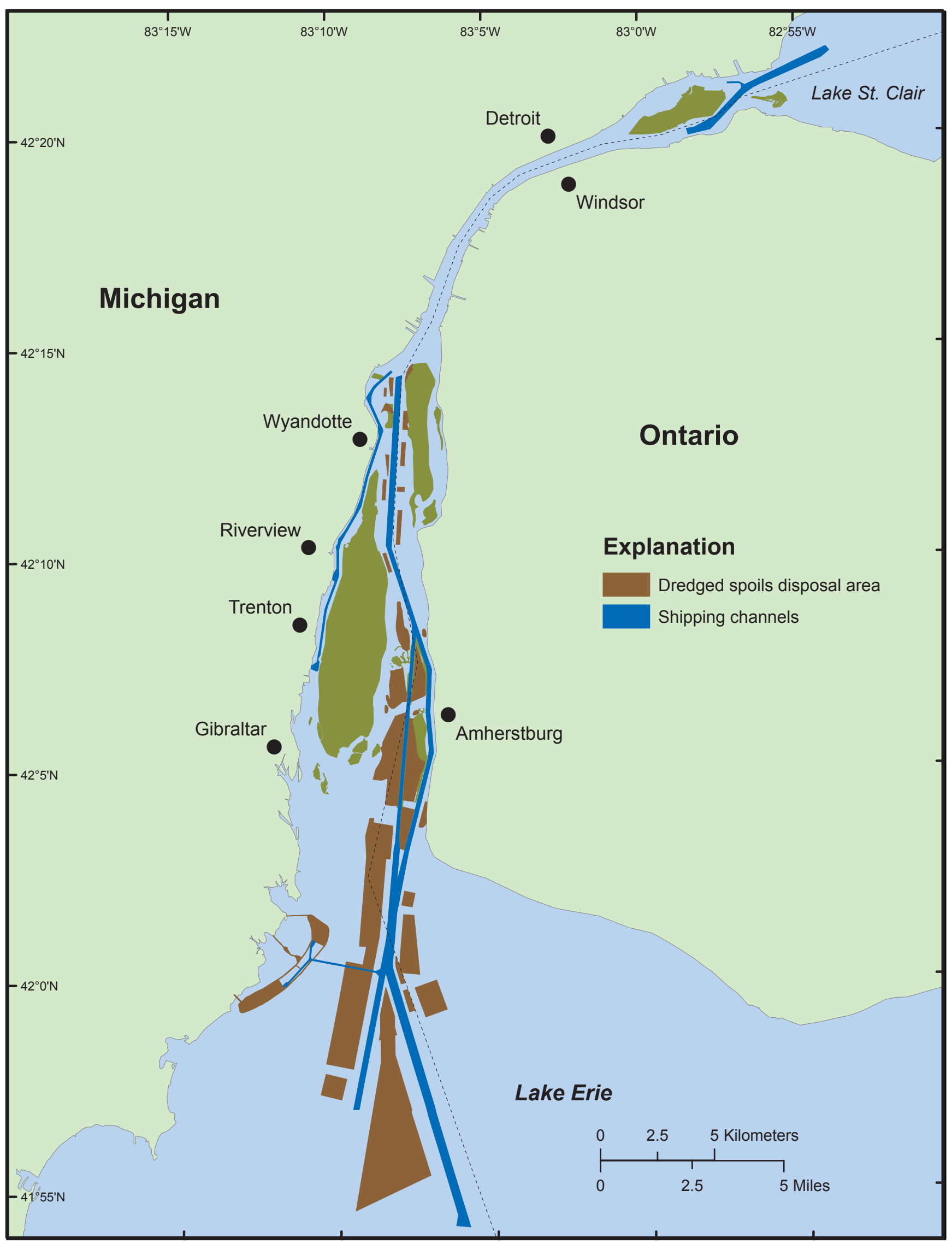

Figure 5. Extent of Detroit River channel construction and dredged spoil disposal works in 2003. 


\section{Environmental Consequences}

The International Workshop on the Science and Management for Habitat Conservation and Restoration Strategies (HabCARES) suggests that there are three choices society can make when determining how to respond to a degraded ecosystem like the Detroit River: (1) No changes can be made, leading to continued degradation; (2) a policy of no net change can be put in place to maintain the current state; or (3) the policy of no net change can be used as a placeholder until habitat-restoration efforts exceed net habitat destruction (Kelso and Wooley, 1996). Recently, a consortium of Federal, state, and local partners has chosen to use retrospective analysis to guide habitat restoration in the Huron-Erie Corridor (HEC) and fulfill the goals of the Huron Erie Corridor Initiative (www.huron-erie.org).

Although environmental and habitat consequences of Detroit River construction activities were not quantified at the time, primary ecological consequences of these channel alterations included losses of fish spawning habitat and more focused (rather than diffuse) discharge of the Detroit River into Lake Erie (Manny and others, 2005a). This latter effect could reduce the survival of fish larvae drifting out of the Detroit River (cf. Manny and others, 2007; Roseman and others, 2007). As of 2003, a total area of 5,925 ha has been affected by shipping channel projects in the Detroit River (fig. 5). Water levels upstream of the Detroit River in Lake St. Clair and Lake Huron are another factor that is influenced by channel construction. Upstream water level was an important issue to the shipping interests because any deficiency in project depth would result in financial loss due to decreased cargo load sizes. Although considered in construction projects starting with the Livingston Channel, the long-term aspects of lake-level variability were and are not now fully understood. This uncertainty is indicated by the frequent recommendations in the congressional reports to continue or enhance extended monitoring and study of upstream water levels as projects progressed. The 1946 uncompleted project to deepen and widen the Amherstburg and Ballards Reef channels involved extensive compensating works that would have severely reduced the outflow of the Trenton Channel. When these projects were revisited and expanded in 1955, it was stated that Lake St. Clair water levels had risen $2.1 \mathrm{~cm}$ because of overcompensation in past projects and that less extensive compensating works were needed for current projects (U.S. Senate, 1955).
These judgments were based on the best science available at the time, but current water-level issues demonstrate that even after 100 years of study, the magnitude of change various causes exert on lake levels is still debated (Wilcox and others, 2007).

As agencies were created to address environmental impacts of channel-construction projects, the environmental effects of these works were considered to a greater extent in the construction planning process and, in some cases, environmental assessments greatly altered or halted proposed plans.

Recovery time for natural resources from environmental alteration on the scale that occurred in the Detroit River can be over 100 years (Petts, 1987). Perhaps the appearance of spawning Lake Whitefish and their successful reproduction in the Detroit River in 2005 for the first time in 80 years was not a coincidence (Roseman and others, 2007). Implementing the projects to enlarge the Detroit River's shipping channels recently studied by the Corps (U.S. Army Corps of Engineers, 2003a) would entail blasting and dredging of large amounts of river-bottom material. For example, the deepening of shipping channels in the Detroit River to $9.1 \mathrm{~m}$ or $10.7 \mathrm{~m}$ would require that approximately $152,910,000 \mathrm{~m}^{3}$ or $382,200,000$ $\mathrm{m}^{3}$ of river-bottom materials, respectively, would need to be excavated and disposed of. Although the dredging would take place in existing channels, the impacts of resuspended polluted sediments and the large areas required to dump the dredged material could again adversely affect ecological functions and productivity of fish and wildlife resources throughout large portions of the Detroit River. Careful forecasting of needs, planning of projects, and a thorough understanding of project environmental impacts could help minimize the financial and ecological costs in future channel-construction projects.

\section{Acknowledgments}

We thank Chris Schmuckal and Jeffrey Allen for assistance in finding historical reports and Dan Benes and Sandra Morrison for technical assistance; all are our fellow workers at the USGS Great Lakes Science Center in Ann Arbor, Mich. This research was supported in part by the USGS Great Lakes Science Center, the USGS Science Support Program, and the U.S. Environmental Protection Agency. This article is Contribution 1604 of the USGS Great Lakes Science Center. 


\section{References}

Bull, J.N., and Craves, J., 2003, Biodiversity of the Detroit River and environs-Past, present, and future prospects, in Hartig, J.H., ed., Honoring our Detroit River: Bloomfield Hills, Mich., Cranbrook Institute of Science, p. 141-169.

Carl, L., Bennion, D., Roseman, E., Morrison, S., and Todd, T., 2007, Importance of historical data in the development of fish restoration strategies: Poster presented at the Second National Conference on Ecosystem Restoration, Kansas City, Mo., April 23-27, 2007.

Derecki, J.A., 1985, Effect of channel changes in the St. Clair River during the present century: Journal of Great Lakes Research, v. 11, p. 201-207.

Farmer, Silas, 1884, The history of Detroit and Michigan: Detroit, Mich., Silas Farmer \& Co., p. 16, accessed July 10, 2007 at http://books.google.com/books? id $=2 d t M H B x D 6 R$ $8 C \& d q=S I L A S+$ Farmer + History + of + Detroit $\& p g=$ RA1PR27\&ots $=n 9 t L i 00 O u V \&$ sig $=$ TuYakMLuSyuqqKD5Ck3Sl itiFt0\&prev=http://www.google.com/search\%3Fhl\%3Den $\% 26 q \% 3 D$ SILAS\%2BFarmer\%2BHistory\%2Bof\%2BDetro $i t \% 26$ safe $\% 3$ Dactive \&sa $=X \&$ oi $=$ print $\& c t=$ result $\& c d=1 \#$ PRA1-PA16,M1.

Goodyear, C.D., Edsall, T.A., Demsey, D.M., Moss, G.D., and Polanski, P.E., 1982, Atlas of the spawning and nursery areas of Great Lakes fishes: U.S. Fish and Wildlife Service, FWS/OBS-82-52, v. 1-14.

Great Lakes St. Lawrence Seaway Study, 2007, accessed November 27, 2007 at http://www.glsls-study.com/ English\%20Site/home.html.

Hartig, J.H., 2003a, The Greater Detroit American Heritage River Initiative and the future, in Hartig, J.H., ed., Honoring our Detroit River: Bloomfield Hills, Mich., Cranbrook Institute of Science, p. 199-223.

Hartig, J.H. 2003b, Introduction, in Hartig, J.H., ed., Honoring our Detroit River: Bloomfield Hills, Mich., Cranbrook Institute of Science, p. 1-8.

Horton, R.E., and Grunsky, C.E., 1927, Hydrology of the Great Lakes: Report of the Engineering Board of Review of the Sanitary District of Chicago on the Lowering Controversy and a Program of Remedial Measures, part 3, appendix 2 .

Kelso, J.R.M., and Wooley, C., 1996, Introduction to the International Workshop on the Science and Management for Habitat Conservation and Restoration Strategies (HabCARES): Canadian Journal of Fisheries and Aquatic Sciences, v. 53, suppl. 1, p. 1-2.
LaPointe, N.W.R., 2005, Fish-habitat associations in shallow Canadian Waters of the Detroit River: Windsor, Ontario, University of Windsor, M.S. thesis, 139 p.

Larson, J.W., 1981, Essayons-A history of the Detroit District, U.S. Army Corps of Engineers: U.S. Government Printing Office, 1981-0-750-976, 215 p.

Library of Congress [n.d.], Prints \& Photographs Division, Detroit Publishing Company Collection, reproduction no. LC-D4-72002.

Livingstone, W.A., 1891, The Great Lakes Problem; or The "twenty foot channel"...: Detroit, Mich. [work housed at University of Michigan Library, Buhr Shelving Facility, HE398.L79], 38 p.

Manny, B.A., 2003, Setting priorities for conserving and rehabilitating Detroit River habitats, in Hartig, J.H., ed., Honoring our Detroit River: Bloomfield Hills, Mich., Cranbrook Institute of Science, p. 121-139.

Manny, B.A., Bennion, D., Allen, J., and Roseman, R., 2006, The Livingstone Channel Project: Presentation to the 2006 Annual Meeting of the International Association of Great Lakes Research, Windsor, Ontario, May 24, 2006.

Manny, B.A., Carl, L.M., Morrison, S., Nichols, S.J., Roseman, E.F., and Riley, S.C., 2005a, The U.S. Geological Survey Huron-Erie Corridor Initiative, in Eedy, R., Hartig, J., Bristol, C., Coulter, M., Mabee, T., and Ciborowski, J., eds., State of the Strait-Monitoring for sound management: Windsor, Ontario, University of Windsor, Great Lakes Institute for Environmental Research, Occasional Publication No. 4, p. 92-97.

Manny, B.A., Edsall, T.A., and Jaworski, E., 1988, The Detroit River, Michigan-An ecological profile: U.S. Fish and Wildlife Service Biological Report 85(7.17), 86 p.

Manny, B.A., and Kenaga, D., 1991, The Detroit RiverEffects of contaminants and human activities on aquatic plants and animals and their habitats: Hydrobiologia, v. 219, p. 269-279.

Manny, B.A., and Kennedy, G.W., 2002, Known lake sturgeon (Acipenser fulvescens) spawning habitat in the channel between Lakes Huron and Erie in the Laurentian Great Lakes: Journal of Applied Ichthyology, v. 18, p. 486-490.

Manny, B.A., Kennedy, G.W., Allen, J.D., and French, J.R.P., III, 2007, First evidence of egg deposition by walleye (Sander vitreus) in the Detroit River: Journal of Great Lakes Research, v. 33, p. 512-516. 
Manny, B.A., Read, J., Denison, D., Reider, R., Kennedy, G., Caswell, N., Boase, J., and McClain, J., 2005b, Creation of lake sturgeon spawning habitat in the Detroit River, in Eedy, R., Hartig, J., Bristol, C., Coulter, M., Mabee, T., and Ciborowski, J., eds., State of the Strait-Monitoring for sound management: Windsor, Ontario, University of Windsor, Great Lakes Institute for Environmental Research, Occasional Publication No. 4, p. 98-100.

Mansfield, J.B., ed., 1899, History of the Great Lakes, Volume I: Chicago, J. H. Beers \& Co.

Milner, J.W., 1873, Report on the fisheries of the Great Lakes; The results of inquiries prosecuted in 1871 and 1872: U.S. Commission of Fisheries, Annual Report, p. 12-13.

Moulton, R., and Thieme, S., 2009, History of dredging and compensation-St. Clair and Detroit Rivers, accessed 06/10/2010 at http://pub.iugls.org/en/St_Clair_Reports/ Sediment/Sediment-05.pdf.

Nolan, Jenny, 1997, How the Detroit River shaped lives and history: Detroit News, February 11, 1997, accessed October 25, 2006, at http://info.detnews.com/history/story/index. cfm? id $=186 \&$ category=locations.

Petts, G.E., 1987, Time-scales for ecological change in regulated rivers, in Craig, J.F., and Kemper, J.B., eds., Regulated streams - Advances in ecology: New York, Plenum Press, p. 257-266.

Quinn, F.H., 1985, Temporal effects of St. Clair River dredging on lakes St. Clair and Erie water levels and connecting channel flow: Journal of Great Lakes Research, v. 11, no. 3, p. 400-403.

Roseman, E.F., Kennedy, G.W., Boase, J., Manny, B.A., Todd, T.N., and Stott, W., 2007, Evidence of lake whitefish spawning in the Detroit River-Implications for habitat and population recovery: Journal of Great Lakes Research, v. 33, p. 397-406.

Schloesser, D.W., and Manny, B.A., 2007, Restoration of wildcelery, Vallisneria americana Michx., in the lower Detroit River of the Lake Huron-Lake Erie Corridor: Journal of Great Lakes Research, v. 33 (suppl. 1), p. 8-19.

Smith, H.M., 1915, Report of the Commissioner of Fisheries: Report for the fiscal year 1914, with appendixes.

Smith, H.M., 1917, Report of the Commissioner of Fisheries. Report for the fiscal year 1916, with appendixes.

Steedman, R.J., Whillans, T.H., Behm, A.P., Bray, K.E., Cullis, K.I., Holland, M.M., Stoddart, S.J., and White, R.J., 1996, Use of historical information for conservation and restoration of Great Lakes aquatic habitat: Canadian Journal of Fisheries and Aquatic Sciences, v. 53 (suppl. 1), p. 415-423.
U.S. Army Corps of Engineers, 1915, Annual Report of the Chief of Engineers 1915: Washington, D.C., Government Printing Office.

U.S. Army Corps of Engineers, 1938, Annual Report of the Chief of Engineers 1938: Washington, D.C., Government Printing Office.

U.S. Army Corps of Engineers, 2000, Waterborne commerce of the United States, calendar year 2000. Part 3Waterways and harbors, Great Lakes: New Orleans, La., U.S. Army Corps of Engineers, Waterborne Commerce Statistics Center.

U.S. Army Corps of Engineers, 2003a, Reconnaissance report, Great Lakes Navigation System Review: Detroit, Mich., U.S. Army Corps of Engineers.

U.S. Army Corps of Engineers, 2003b, Annual report of the Chief of Engineers, U.S. Army, on Civil Works Activities for 2003: Washington, D.C., U.S. Government Printing Office.

U.S. Army Corps of Engineers, 2004, Waterborne commerce of the United States, calendar year 2004. Part 3Waterways and harbors, Great Lakes: New Orleans, La., U.S. Army Corps of Engineers, Waterborne Commerce Statistics Center.

U.S. House of Representatives, 1900, Preliminary report on survey of the Detroit River, Michigan: U.S. Congress, 56th, 1st session, House Document No. 712, 6 p.

U.S. House of Representatives, 1904, Detroit River, Michigan: U.S. Congress, 58th, 3d session, House Document No. 40, $6 \mathrm{p}$.

U.S. House of Representatives, 1906, Ship Channel Connecting Waters of the Great Lakes: U.S. Congress, 59th, 2d session, House Document No. 266, 20 p.

U.S. House of Representatives, 1910, Livingstone Channel Detroit River, Michigan: U.S. Congress, 61st, 2d session, House Document No. 676, 25 p.

U.S. House of Representatives, 1911, Detroit River, Wyandotte Channel, Mich.: U.S. Congress, 62d, 1st session, House Document No. 17, 7 p.

U.S. House of Representatives, 1917, Livingstone Channel, Detroit River, Mich.: U.S. Congress, 65th, 1st session, House Document No. 322, 25 p.

U.S. House of Representatives, 1928, Great Lakes-Connecting Waters, Principal Harbors, and River Channels: U.S. Congress, 70th, 1st session, House Document No. 253, 96 p.

U.S. House of Representatives, 1946, Detroit River, Mich.: U.S. Congress, 79th, 2d session, House Document No. 734, $11 \mathrm{p}$. 
U.S. House of Representatives, 1948, Great Lakes Connecting Channels: U.S. Congress, 80th, 1st session, House Document No. 335, 115 p.

U.S. House of Representatives, 1959, Great Lakes Harbors Study-Interim Report on Detroit River, Trenton Channel, Mich.: U.S. Congress, 86th, 2d session, House Document No. 319,51 p.

U.S. House of Representatives, 1968, Detroit River, Trenton Channel, Michigan: U.S. Congress, 90th, 2d session, House Document No. 338, 126 p.

U.S. Senate, 1949, Improvement of the Trenton Channel, Detroit River, Mich.: U.S. Congress, 81 st, 1st session, Senate Document No. 30, 30 p.
U.S. Senate, 1955, Great Lakes Connecting Channels: U.S. Congress, 84th, 1st session, Senate Document No. 71, 88 p.

Wei, A., Chow-Fraser, P., and Albert, D., 2004, Influence of shoreline features on fish distribution in the Laurentian Great Lakes: Canadian Journal of Fisheries and Aquatic Sciences, v. 61, p. 1113-1123.

Wilcox, D.A., Thompson, T.A., Booth, R.K., and Nicholas, J.R., 2007, Lake-level variability and water availability in the Great Lakes: U.S. Geological Survey Circular 1311, $25 \mathrm{p}$. 

 \\ ¿USGS

. \\ (n) Manny-Construction of Shipping Channels in the Detroit River: History and Environmental Consequences-Scientific Investigations Report 2011-5122} B. 